\title{
Small-scale Variation in a Benthic Community at an Intertidal Flat in Thailand: Effects of Spatial Heterogeneity of Seagrass Vegetation
}

\author{
Masahiro Nakaoka* \\ Ocean Research Institute, University of Tokyo, Minamidai 1-15-1, Nakano, \\ Tokyo 164-8639, Japan
}

\begin{abstract}
I examined the diversity and abundance of benthic animal communities in an intertidal seagrass bed at Haad Chao Mai National Park, Thailand, in relation to small-scale spatial heterogeneity of the seagrass vegetation. In this seagrass bed, two dominant seagrasses, Halophila ovalis and Thalassia hemprichii, coexist in a mosaic of monospecific vegetation. I collected benthic animals at the center, edge and outside of the $H$. ovalis vegetation at one site that bordered an unvegetated sand flat and at another site surrounded by $T$. hemprichii vegetation. A total of 3146 benthic animals from 61 taxa were collected. The most numerious species was the lucinid bivalve Pillucina sp., composing more than $60 \%$ of the individuals. Although the species composition of benthic animals did not differ largely among the three positions at each site, taxa richness (the number of taxa) was higher in the center of the $H$. ovalis vegetation than the edge of and outside the vegetation. Among the four dominant taxa, Pillucina sp. and a sabellid polychaete were generally more abundant in the center of the vegetation than at the edge of and outside the vegetation, whereas significant variation among positions was not detected in the densities of capitellid and spionid polychaetes. Significant among-position variation was also detected in the relative abundance of some taxa. The patterns of among-position variation in taxa richness and abundance did not differ between the two sites. These findings suggest that small-scale spatial heterogeneity of seagrass vegetation has a great impact on the diversity and abundance of benthic communities in intertidal seagrass beds, and that the responses of benthic animals to habitat heterogeneity are species specific.
\end{abstract}

Key words: abundance, benthic animals, diversity, seagrass, spatial heterogeneity, Thailand

\section{INTRODUCTION}

Spatial structure in habitats plays a critical role in determining community dynamics (Bell et al. 1991; Tilman 1994; Tilman \& Kareiva 1997). The effects of habitat structure on community dynamics is a central topic in conservation ecology, especially in relation to the effects of habitat fragmentation (Saunders et al.

Received April 24, 2001: Accepted September 3, 2001

* Present address: Graduate School of Science and Technology, Chiba University, Yayoi-cho 1-33, Inage, Chiba 263-8522, Japan.
1991; Robinson et al. 1995). In marine systems, experimental analyses on the effects of spatial structure within habitats have been carried out intensively in rocky intertidal communities (Paine \& Levin 1981; Sousa 1984; Noda 1999), and more recently, in soft bottom communities (Irlandi 1994; Robbins \& Bell 1994; Bell et al. 1995; Reusch \& Williams 1999).

The presence of marine macrophytes, such as seagrasses and kelps, enhances the abundance and diversity of associated animal assemblages by providing food, habitat and shelter (see reviews in Orth \& van Montfrans 1984; Mazzella et al. 1992; Orth 1992; Jernakoff et al. 1996). In general, the vegetation patterns of these macrophytes are not uniform. Rather, 
they show large spatial heterogeneity in their distribution, containing monospecific and/or multispecific patches and unvegetated gaps of various sizes of ten arranged in complex configurations (Marbà \& Duarte 1995; Vidondo et al. 1997; Nakaoka \& Aioi 1999). Recent studies on the effects of the spatial heterogeneity of macrophyte distribution on animal populations and communities found that spatial structure of macrophytes (e.g., size and shape of patches, and their spatial arrangements) influences the species richness and abundance of animal communities, and the population dynamics of the component species (Stoner \& Lewis 1985; Bell \& Hicks 1991; Bologna \& Steneck 1993; Irlandi 1994, 1996, 1997; Eggleston et al. 1998; Reusch $\&$ Williams 1999). However, the directions and magnitudes of the responses of animals to habitat spatial structures vary from case to case, precluding the establishment of general patterns. In particular, very few data are available on the variation that occurs in animal communities at small spatial scales, e.g., within a single macrophyte patch (Reusch \& Williams 1999). Examination of small-scale variation in benthic communities is important because the presence of such variation may influence the accuracy of benthic abundance and diversity estimates over large scales.

To provide a first step to elucidate the effects of spatial heterogeneity of seagrass distribution on benthic communities, I conducted a quantitative study at a seagrass bed in Haad Chao Mai National Park, one of the largest seagrass beds along the southwestern coast of Thailand (Lewmanomont et al. 1996; Lewmanomont \& Supanwanid 2000). The intertidal part of the seagrass bed consists of eight seagrass species (Lewmanomont \& Supanwanid 2000). Halophila ovalis and Thalassia hemprichii are dominant and form a mosaic of monospecific patches that overlap only at patch margins (Nakaoka \& Iizumi 2000; Nakaoka \& Supanwanid 2000). Such spatial heterogeneity in seagrass distribution can have a great influence on seagrass growth and productivity, and on epifaunal communities (Nakaoka \& Aioi 1999; Nakaoka \& Iizumi 2000; Nakaoka \& Toyohara 2000). It is expected that the effects further extend to benthic animals, including infaunal animals, in the seagrass bed.

The aim of the present paper is to determine whether the diversity and abundance of benthic animals vary with small-scale spatial heterogeneity of the vegetation of $H$. ovalis. I collected and compared benthic communities among two different positions within the $H$. ovalis vegetation and one position outside the vegetation. These comparisons were made at one site where the $H$. ovalis vegetation bordered an unvegetated sand flat and at another site surrounded by $T$. hemprichii vegetation to investigate the possible effects of adjacent vegetation on small-scale variation in benthic communities.

\section{MATERIALS AND METHODS}

\section{Study site}

I carried out the fieldwork in December 1998 at an intertidal seagrass bed in Laem Yong Lam, Haad Chao Mai National Park (Fig. 1A). The area of the intertidal flat is ca $3 \mathrm{~km}^{2}$ (Nakaoka \& Supanwanid 2000). The tidal range in the area varies between $0.7 \mathrm{~m}$ (neap tide) and $2.8 \mathrm{~m}$ (spring tide). At the upper parts of the intertidal flats (shallower than $-1 \mathrm{~m}$ deep at Lowest Low Water), H. ovalis and T. hemprichii are the dominant species, followed by Enhalus acoroides, Cymodocea rotundata and Halodule uninervis (Nakaoka \& Supanwanid 2000).

The two dominant seagrass species coexist in a mosaic of monospecific patches (hereafter called "vegetation") that border either vegetation of another species or an unvegetated sand flat. I established two study sites (each ca $20 \times 20 \mathrm{~m}$ in area) containing $H$. ovalis vegetation. At one site (called "HS site"), the $H$. ovalis vegetation bordered an unvegetated sand flat, and at the other site ("HT site"), the vegetation was surrounded by adjoining $T$. hemprichii vegetation (Fig. 1B). The two sites were located $100 \mathrm{~m}$ apart.

Halophila ovalis vegetation at both sites was located at the same tidal level ( $-1.5 \mathrm{~m}$ at LLW). Thalassia hemprichii vegetation at the HT site was depressed $5-7 \mathrm{~cm}$ below the $H$. ovalis vegetation, forming tide pools at low tide. The tidal elevation was the same both outside and inside of the $H$. ovalis vegetation at the HS site.

To examine the sediment characteristics, sediment samples were randomly collected to a depth of $5 \mathrm{~cm}$ with a cylindrical tube of $5 \mathrm{~cm}$ diameter inside and outside of the $H$. ovalis vegetation at both sites. Four replicate samples were collected from each position. The collected sediment samples were dried in an oven at 60 ${ }^{\circ} \mathrm{C}$ to constant weight and weighed on an electronic balance. They were then sieved through a series of sieves consisting of $1,0.5,0.25,0.125$ and $0.063 \mathrm{~mm}$ mesh openings. Each fraction was dried and weighed again. The median diameter, silt-clay content and inclusive graphic standard deviation (sorting coefficient) were then calculated according to the method of Buchanan 
(1984).

\section{Collection and measurement of benthic animals}

Quantitative sampling of benthic animals was carried out when the intertidal flat was exposed to air during the daytime low tide. I collected sediments using a 10 $\mathrm{cm} \times 10 \mathrm{~cm}$ square core to a depth of $10 \mathrm{~cm}$. At each site, I randomly collected eight replicate samples from each of three positions: (1) at the center of the $H$. ovalis vegetation (center), (2) at the outer edge of the vegetation (edge), and (3) outside the vegetation (outside; i.e., from the unvegetated sand flat at the HS site, and from the T. hemprichii vegetation at the HT site). The border of the vegetation was determined visually, although a small amount of $H$. ovalis (less than $0.06 \mathrm{~g}$ dry weight per $0.01 \mathrm{~m}^{2}$ area; Nakaoka, unpublished data) was sometimes found outside the vegetation. The center was defined as positions more than $1 \mathrm{~m}$ inside the border of the $H$. ovalis vegetation, and the edge was defined as locations less than $30 \mathrm{~cm}$ from the borders. Outside locations were located more than $1 \mathrm{~m}$ from the borders.

In the field, the collected sediment was sieved through a sieve with a $0.5 \mathrm{~mm}$ mesh opening, and fixed and preserved in $10 \%$ neutralized seawater formalin. In the laboratory, all animals retained on a $1 \mathrm{~mm}$ mesh sieve were sorted out, counted and classified to species or higher taxa depending on the taxonomic information available. Most animals were classified to species-level taxon based on observations under a microscope. For some groups, such as diastomid gastropods and capitellid polychaetes, however, it was not possible to identify all individuals to species level due to a lack of taxonomic information and to logistical constraints. For example, the capitellid polychaetes comprised several different genera, such as Heteromastus sp., Mediomastus sp. and Notomastus sp. (K. Yabe, personal communication). These groups were categorized into one taxon.

To examine spatial variation in seagrass abundance and composition, I collected four additional samples using a $20 \mathrm{~cm} \times 20 \mathrm{~cm}$ square quadrat to a depth of $10 \mathrm{~cm}$ at both the center and edge of the HS and HT sites, and outside of the $H$. ovalis vegetation at the HT site (i.e., in the $T$. hemprichii vegetation). Aboveground and belowground parts of the two seagrasses were sorted, dried in an oven at $60^{\circ} \mathrm{C}$ to a constant weight, and weighed on an electronic balance.
A

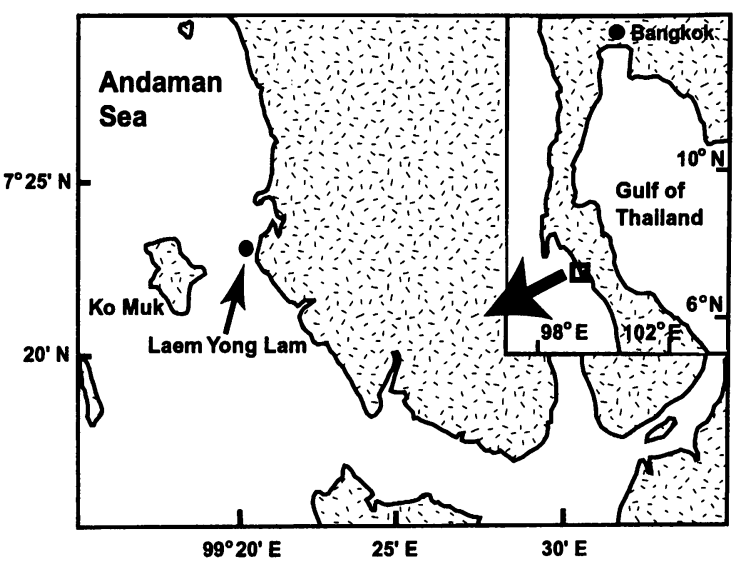

B

济: H. ovalis vegetation; $\downarrow \downarrow$ : T. hemprichil vegetation

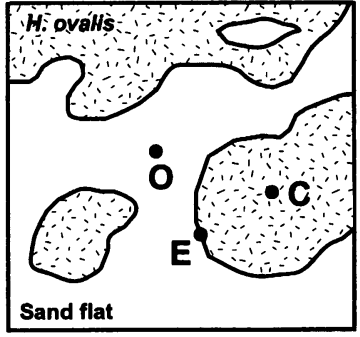

HS site

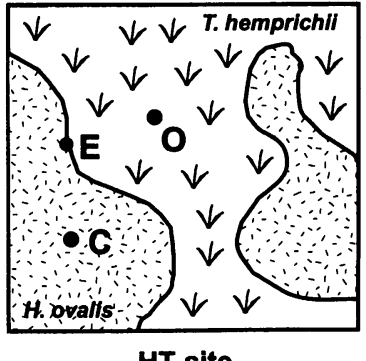

HT site
Fig. 1. (A) Location of the study site (Laem Yong Lam) at Haad Chao Mai National Park in Thailand, and (B) schematic presentation of spatial structure of the seagrass vegetation and positions of benthic collection (C: center of the Halophila ovalis vegetation, E: edge of the vegetation, $\mathrm{O}$ : outside the vegetation) at the two study sites (HS and HT sites).

\section{Data analyses}

Differences in sediment composition (median diameter, silt-clay content and inclusive graphic standard deviation) between the inside and outside of the $H$. ovalis vegetation at each site were tested using a $t$-test.

Benthic community structure was analyzed by comparing the taxa richness (the number of taxa occurring in each sample) and the densities and the relative abundances of the dominant animals at each site. Only four dominant taxa (Pillucina sp., Capitellidae spp., Sabellidae sp.1 and Spionidae sp.1) were analyzed because abundances of the other species were too low (average of $<0.5$ individuals per quadrat) for powerful statistical testing. 
The effects of position in and near the $H$. ovalis vegetation on taxa richness were tested for each site using one-way ANOVA. To test among-position variation in the densities of dominant taxa, multivariate ANOVA (MANOVA) was carried out using the logarithm of the densities of the four dominant species as dependent variables. In cases when significant variation was detected by MANOVA, ANOVA was carried out separately for each dominant taxon. Prior to the ANOVA, homoscedasticity of the data was tested using Cochran's $C$ test (Underwood 1997), and in cases where a significant difference in variance was detected, data were log-transformed to secure the homogeneity of variances. When significant variation among the three positions was detected by ANOVA, post-hoc comparisons were carried out using the Student-Newman-Keuls (SNK) test by setting the error rate at $P=0.05$.

Within-site variation in relative abundance of the dominant taxa (i.e., the proportion that each taxon formed of the total number of benthic animals collected at each position of the two sites) was tested using a $\chi^{2}$ test against the null hypothesis that the proportion of each taxon was the same at the three positions. Data from eight replicate samples were pooled for each position in this analysis.

\section{RESULTS}

Sediments at the two sites consisted of fine sand (median diameter of 2 to 3 in phi unit), with the silt-clay content varying between 4 and $7 \%$, and the inclusive graphic standard deviation between 0.58 and 0.78 (Table 1). These parameters differed significantly between the inside and outside of the HT site, where the sediment was finer and less sorted inside the $H$. ovalis vegetation than outside (i.e., in the $T$. hemprichii vegetation). At the HS site, on the other hand, the sediment composition did not differ significantly inside and outside the $H$. ovalis vegetation (Table 1 ).

The seagrass vegetation was composed of only $H$. ovalis at the HS site, where the aboveground and belowground biomass was about twice as high at the center than the edge (Fig. 2). Seagrass at the HT site consisted of only $H$. ovalis at the center, of only $T$. hemprichii outside, and of both species at the edge, with $T$. hemprichii occupying more than $80 \%$ of the total biomass. The aboveground and belowground biomass of $H$. ovalis was 3-5 times higher in the center than the edge of the HT site, although seagrass biomass was greater at the edge when $T$. hemprichii was included. The aboveground and belowground biomass of $T$. hemprichii was slightly higher outside than at the edge at the HT site.

A total of 3146 benthic animals were collected from 48 sediment samples and classified into 61 taxa (Table 2 ). Annelid polychaetes were the most numerous in taxon (25 taxa), followed by molluscs (21 taxa) and arthropods (10 taxa). The most abundant species was a lucinid bivalve Pillucina sp. This species occurred in all core samples, and composed $62 \%$ of the total number of benthic animals. Other abundant species included several polychaetes. Capitellidae spp. was the second most abundant taxon (2.7\% of the total number), followed by Sabellidae sp. (1.4\%) and Spionidae sp.1 (1.3\%). Other species contributed to less than $0.8 \%$ of the total number of benthic animals.

Most taxa were collected from various positions at the two sites (Table 2). Seven of the ten dominant taxa (i.e., with a total of $\geq 20$ individuals) were collected from all positions. The three exceptions were Anadara sp., Syllidae spp. and Sabellidae sp., which were collected only within the $H$. ovalis vegetation at the HS site (Table 2). Taxa composition was thus largely similar among the three positions within each site.

The taxa richness of benthic animals tended to be higher at the center of $H$. ovalis vegetation than at the edge and outside the vegetation at the HS site (Fig. 3), although the variation among positions was marginally significant (ANOVA; $F=2.877$; d.f. $=2,21 ; P=$ $0.079)$. At the HT site, the variation was statistically significant among positions (ANOVA; $F=4.237$; d.f. $=2,21 ; P=0.028$ ), and post-hoc comparison revealed that the taxa richness was highest in the center of the H. ovalis vegetation (Fig. 3 ).

For the four dominant benthic taxa, MANOVA revealed significant variation in densities among positions at both the HS site (Pillai's trace $=0.823 ; F=$ 3.319; d.f. $=8,38 ; P=0.006$ ) and the HT site (Pillai's trace $=0.924 ; F=4.076 ;$ d.f. $=8,38 ; P=0.001$ ). Taxaby-taxa comparisons showed that the density of Pillucina sp. was significantly higher at the center than at the edge and outside at both sites, whereas no significant variation was found between the latter two positions (Table 3). The density of Sabellidae sp. showed a similar pattern of variation among positions. The variation was marginally significant at the HS site, but not significant at the HT site (Table 3). For the densities of Capitellidae spp. and Spionidae sp.1, significant variation was not detected among positions at either site (Table 3).

The relative abundances of Pillucina sp. and 
Table 1. Sediment composition at the two study sites (HS and HT) compared between inside and outside of Halophila ovalis vegetation.

\begin{tabular}{|c|c|c|c|c|c|c|c|}
\hline & \multicolumn{2}{|c|}{ Inside } & \multicolumn{2}{|c|}{ Outside } & \multicolumn{3}{|c|}{$T$-test } \\
\hline & mean & se & mean & se & $t$ & $\mathrm{df}$ & $P$ \\
\hline \multicolumn{8}{|l|}{ HS site } \\
\hline Median diameter (phi unit) & 2.51 & 0.02 & 2.57 & 0.02 & 2.151 & 6 & 0.075 \\
\hline Silt-clay content $(\%)^{\mathrm{a}}$ & 4.23 & 0.33 & 4.89 & 0.77 & 0.682 & 6 & 0.521 \\
\hline Inclusive graphic standard deviation & 0.59 & 0.01 & 0.58 & 0.03 & 0.092 & $4^{\mathrm{b}}$ & 0.930 \\
\hline \multicolumn{8}{|l|}{ HT site } \\
\hline Median diameter (phi unit) & 2.65 & 0.02 & 2.44 & 0.02 & 9.655 & 6 & $<0.001$ \\
\hline Silt-clay content $(\%)^{\mathrm{a}}$ & 7.31 & 0.83 & 3.58 & 0.29 & 4.643 & 6 & 0.004 \\
\hline Inclusive graphic standard deviation & 0.78 & 0.03 & 0.69 & 0.01 & 2.805 & $5^{\mathrm{b}}$ & 0.042 \\
\hline
\end{tabular}

${ }^{a}$ Data were arcsine transformed for the $t$-test

${ }^{\mathrm{b}}$ Welch's correction was applied to account for heterogeneous variances

Table 2. Numbers of benthic animals collected in the present study. Data on eight replicate samples (each covering $0.01 \mathrm{~m}^{2}$ area) were combined for each position of the two sites.

\begin{tabular}{|c|c|c|c|c|c|c|c|c|c|c|c|c|c|c|c|}
\hline \multirow[b]{3}{*}{ CHIDARIA } & \multicolumn{3}{|c|}{ HS site } & \multicolumn{3}{|c|}{ HT site } & \multirow{2}{*}{\multicolumn{2}{|c|}{ Total }} & \multicolumn{3}{|c|}{ HS site } & \multicolumn{3}{|c|}{ HT site } & \multirow[t]{2}{*}{ Total } \\
\hline & Center & Edge & Dutside & Center & Edge & utside & & & \multicolumn{3}{|c|}{ Center Edge Outside } & \multicolumn{3}{|c|}{ Center Edge Outside } & \\
\hline & & & & & & & & ANNELIDA (continued) & & & & & & & \\
\hline \multirow[t]{2}{*}{ Ceriantharia sp. } & 0 & 1 & 0 & 0 & 2 & 0 & 3 & Orbiniidae sp. & 1 & 1 & 2 & 1 & 0 & 0 & 5 \\
\hline & & & & & & & & Glyceridae sp. & 4 & 5 & 10 & 4 & 2 & 2 & 27 \\
\hline MOLLUSCA & & & & & & & & Lumbrineridae sp. 1 & 0 & 1 & 0 & 1 & 1 & 1 & 4 \\
\hline Mytillidae sp. 1 & 3 & 1 & 0 & 10 & 0 & 1 & 15 & Lumbrineridae sp. 2 & 5 & 2 & 0 & 7 & 0 & 1 & 15 \\
\hline Mytillidae sp. 2 & 0 & 0 & 0 & 3 & 0 & 0 & 3 & Maldanidae sp. & 5 & 10 & 10 & 2 & 2 & 1 & 30 \\
\hline Pillucina sp. & 697 & 321 & 351 & 639 & 244 & 243 & 2495 & Sigambra sp. & 2 & 3 & 4 & 2 & 3 & 0 & 14 \\
\hline Anadara sp. & 12 & 1 & 0 & 4 & 2 & 1 & 20 & Syllidae spp. & 10 & 4 & 0 & 4 & 2 & 2 & 22 \\
\hline Myasidae sp. & 1 & 2 & 0 & 0 & 2 & 1 & 6 & Chaetopteridae sp. & 0 & 0 & 0 & 4 & 9 & 3 & 16 \\
\hline Veremolpa sp. & 3 & 0 & 2 & 3 & 2 & 2 & 12 & Oweniidae sp. & 1 & 0 & 0 & 0 & 0 & 0 & 1 \\
\hline Mactridae sp. & 0 & 0 & 0 & 0 & 0 & 1 & 1 & Opheliidae sp. & 3 & 2 & 0 & 1 & 3 & 4 & 13 \\
\hline Tellinidae sp. & 2 & 0 & 0 & 1 & 0 & 2 & 5 & Sabellidae sp. & 19 & 8 & 0 & 18 & 5 & 5 & 55 \\
\hline Anomalocardia squamos & 0 & 0 & 0 & 0 & 1 & 6 & 7 & Terebellidae sp. & 1 & 0 & 0 & 0 & 0 & 1 & 2 \\
\hline Paphia gallus & 2 & 0 & 0 & 0 & 1 & 0 & 3 & Eunicidae sp. & 0 & 1 & 0 & 0 & 0 & 0 & 1 \\
\hline Unidentified bivalve sp. & 0 & 0 & 0 & 0 & 1 & 0 & 1 & Unidentified polychaete spp. & 0 & 0 & 0 & 2 & 0 & 1 & 3 \\
\hline Nassariidae sp. & 1 & 2 & 1 & 1 & 0 & 0 & 5 & & & & & & & & \\
\hline Pyramidellidae sp. & 1 & 1 & 0 & 2 & 0 & 0 & 4 & ECHIURA & & & & & & & \\
\hline Zafra spp. & 3 & 1 & 0 & 2 & 0 & 0 & 6 & Echiura sp. & 1 & 1 & 4 & 0 & 2 & 0 & 8 \\
\hline Turridae sp. & 1 & 0 & 7 & 1 & 0 & 1 & 10 & & & & & & & & \\
\hline Diastomidae spp. & 2 & 2 & 0 & 0 & 0 & 0 & 4 & SIPUNCULA & & & & & & & \\
\hline Clypeomorus trailli & 4 & 1 & 0 & 1 & 1 & 0 & 7 & Sipunculidae sp. & 0 & 0 & 0 & 0 & 1 & 1 & 2 \\
\hline Clithon chlorostoma & 1 & 0 & 0 & 4 & 0 & 2 & 7 & & & & & & & & \\
\hline Rissoridae sp. & 9 & 6 & 1 & 1 & 1 & 7 & 25 & ARTHROPODA & & & & & & & \\
\hline Decorifer sp. & 0 & 1 & 0 & 0 & 0 & 0 & 1 & Macrophthulmus quadratus & 1 & 1 & 0 & 0 & 0 & 0 & 2 \\
\hline \multirow[t]{2}{*}{ Unidentified gastropod sp. } & 4 & 0 & 0 & 0 & 0 & 0 & 4 & Unidentified crab sp. & 4 & 0 & 0 & 0 & 0 & 0 & 4 \\
\hline & & & & & & & & Anomura sp. & 9 & 2 & 0 & 0 & 2 & 0 & 13 \\
\hline ANNELIDA & & & & & & & & Alpheidae sp. & 4 & 2 & 1 & 0 & 4 & 3 & 14 \\
\hline Polydora sp. 1 & 4 & 1 & 0 & 10 & 0 & 0 & 15 & Latreutes sp. & 1 & 1 & 0 & 0 & 1 & 0 & 3 \\
\hline Polydora sp. 2 & 0 & 0 & 2 & 2 & 0 & 0 & 4 & Corophiidae sp. & 2 & 2 & 0 & 0 & 1 & 0 & 5 \\
\hline Spionidae sp. 1 & 17 & 15 & 4 & 7 & 3 & 8 & 54 & Anthuridea sp. & 0 & 0 & 0 & 1 & 0 & 0 & 1 \\
\hline Spionidae sp. 2 & 2 & 1 & 0 & 0 & 0 & 0 & 3 & Tanaidacea sp. & 1 & 1 & 0 & 2 & 1 & 0 & 5 \\
\hline Spionidae sp. 3 & 3 & 0 & 0 & 0 & 0 & 0 & 3 & Ostracoda spp. & 1 & 1 & 0 & 0 & 0 & 1 & 3 \\
\hline Spionidae sp. 4 & 0 & 1 & 0 & 4 & 0 & 2 & 7 & Pycnogonida sp. & 0 & 0 & 0 & 1 & 0 & 0 & 1 \\
\hline Nereis sp. & 7 & 2 & 7 & 4 & 3 & 2 & 25 & & & & & & & & \\
\hline Polynoidae sp. & 2 & 0 & 1 & 0 & 0 & 0 & 3 & ECHINODERMATA & & & & & & & \\
\hline Capitellidae spp. & 13 & 10 & 27 & 32 & 22 & 6 & 110 & Archaster typicus & 0 & 0 & 0 & 1 & 0 & 0 & 1 \\
\hline Phyllodoce longipes & 1 & 0 & 3 & 0 & 0 & 0 & 4 & Ophiuroidea sp. & 1 & 0 & 0 & 1 & 0 & 0 & 2 \\
\hline Nephtyidae sp. & 0 & 1 & 0 & 0 & 1 & 0 & 2 & Total & 871 & 419 & 437 & 783 & 325 & 311 & 3146 \\
\hline
\end{tabular}




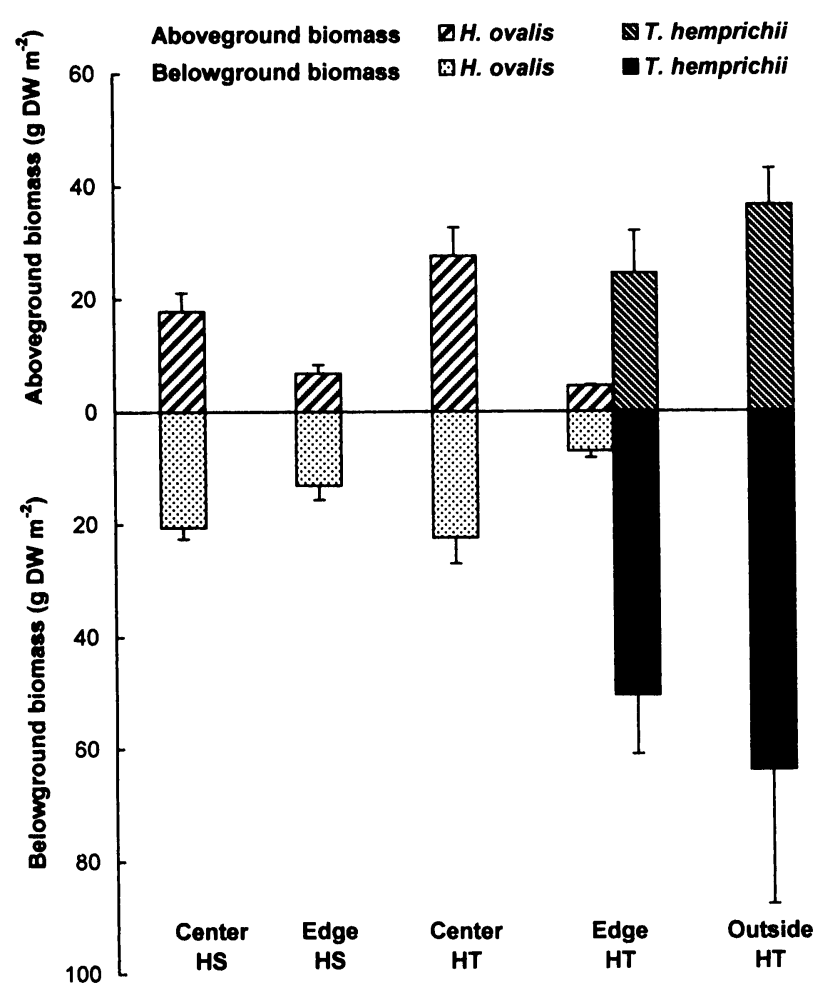

Fig. 2. Aboveground and belowground biomass (in dry weight) of the two seagrasses (Halophila ovalis and Thalassia hemprichii) at various positions of the two study sites (HS and HT sites). Error bars indicate standard errors of the mean. The number of replicates is four for each position.

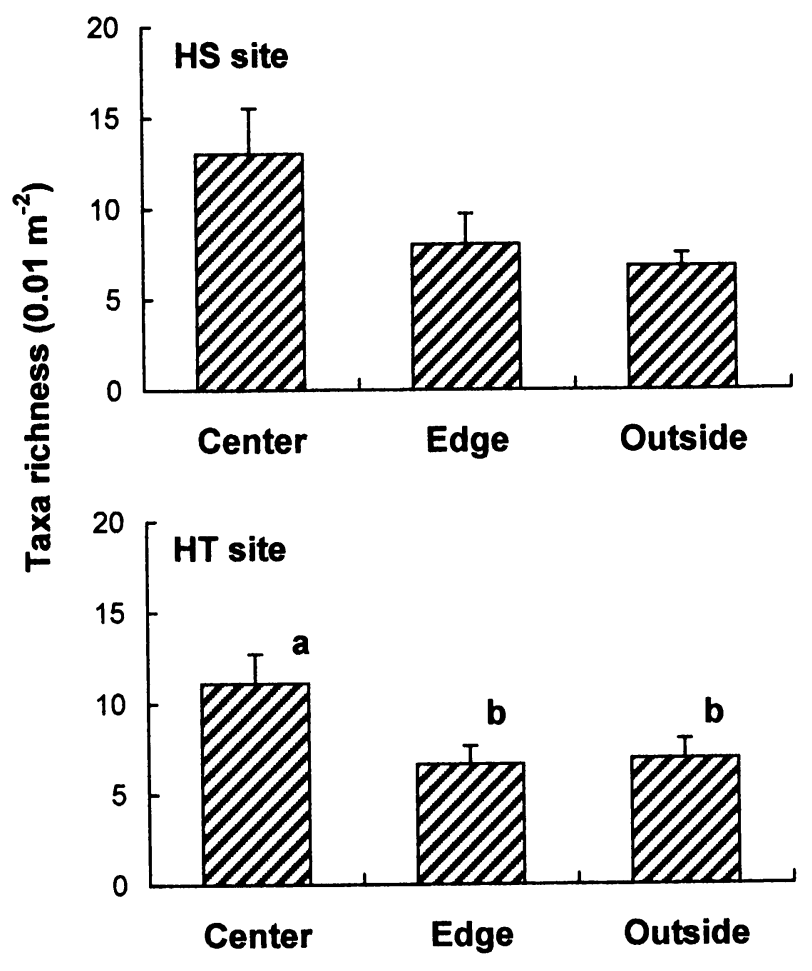

Fig. 3. Taxa richness of benthic animals at three positions within and near the Halophila ovalis vegetation. Error bars indicate standard errors of the mean. Eight replicate samples were collected at each position. Unlike letters denote pairs of positions where significant differences were detected by post-hoc comparison (SNK test; $P$ $=0.05$ ).

Table 3. Comparisons of abundance of four dominant benthic taxa among positions in and near the Halophila ovalis vegetation at the two sites.

\begin{tabular}{|c|c|c|c|c|c|c|c|c|c|c|c|}
\hline \multirow[t]{2}{*}{ Parameters } & \multicolumn{3}{|c|}{$\begin{array}{l}\text { Density }\left(0.01 \mathrm{~m}^{-2} \pm \mathrm{SE} \text {; top column }\right) \text { and } \\
\text { relative abundance }(\% \text {; lower column })\end{array}$} & \multicolumn{6}{|c|}{ ANOVA (for density) } & \multicolumn{2}{|c|}{$\chi^{2}$ test (for relative abundance) } \\
\hline & Center & Edge & Outside & Sources & SS & $\mathrm{df}$ & $F$ & $P$ & $\begin{array}{l}\text { SNK test } \\
(P=0.05)\end{array}$ & $\chi_{\text {cal }}^{2}$ & $P$ \\
\hline \multicolumn{12}{|l|}{ HS site } \\
\hline Density of Pillucina sp. ${ }^{a}$ & $\begin{array}{l}87.1 \pm 17.1 \\
\quad(80.0)\end{array}$ & $\begin{array}{l}40.1 \pm 7.2 \\
\quad(76.6)\end{array}$ & $\begin{array}{c}43.9 \pm 5.7 \\
(80.3)\end{array}$ & $\begin{array}{l}\text { Habitat } \\
\text { Error }\end{array}$ & $\begin{array}{l}0.485 \\
0.840\end{array}$ & $\begin{array}{r}2 \\
21\end{array}$ & 6.068 & 0.008 & $\mathrm{C}>\mathrm{E}=\mathrm{O}$ & 0.497 & $>0.90$ \\
\hline Density of Capitellidae spp. & $\begin{array}{l}1.6 \pm 0.7 \\
(1.5)\end{array}$ & $\begin{array}{l}1.3 \pm 0.6 \\
(2.4)\end{array}$ & $\begin{array}{l}3.4 \pm 1.0 \\
(6.2)\end{array}$ & $\begin{array}{l}\text { Habitat } \\
\text { Error }\end{array}$ & $\begin{array}{r}20.6 \\
101.3\end{array}$ & $\begin{array}{r}2 \\
21\end{array}$ & 2.135 & 0.143 & & 22.527 & $<0.001$ \\
\hline Density of Sabellidae sp. $1^{a}$ & $\begin{array}{l}2.4 \pm 1.1 \\
(2.2)\end{array}$ & $\begin{array}{l}1.0 \pm 0.7 \\
(1.9)\end{array}$ & $\begin{array}{l}0.0 \pm 0.0 \\
\quad(0)\end{array}$ & $\begin{array}{l}\text { Habitat } \\
\text { Error }\end{array}$ & $\begin{array}{l}0.577 \\
1.766\end{array}$ & $\begin{array}{r}2 \\
21\end{array}$ & 3.429 & 0.051 & & 9.083 & $<0.05$ \\
\hline Density of Spionidae sp. 1 & $\begin{array}{l}2.1 \pm 0.7 \\
(2.0)\end{array}$ & $\begin{array}{l}1.9 \pm 0.7 \\
(3.6)\end{array}$ & $\begin{array}{l}0.5 \pm 0.3 \\
(0.9)\end{array}$ & $\begin{array}{l}\text { Habitat } \\
\text { Error }\end{array}$ & $\begin{array}{l}12.3 \\
61.8\end{array}$ & $\begin{array}{r}2 \\
21\end{array}$ & 2.083 & 0.150 & & 7.382 & $>0.05$ \\
\hline \multicolumn{12}{|l|}{ HT site } \\
\hline Density of Pillucina sp. ${ }^{a}$ & $\begin{array}{c}79.9 \pm 17.5 \\
\quad(81.6)\end{array}$ & $\begin{array}{c}30.5 \pm 5.9 \\
\quad(75.1)\end{array}$ & $\begin{array}{c}30.4 \pm 3.8 \\
\quad(78.1)\end{array}$ & $\begin{array}{l}\text { Habitat } \\
\text { Error }\end{array}$ & $\begin{array}{l}0.758 \\
1.073\end{array}$ & $\begin{array}{r}2 \\
21\end{array}$ & 7.420 & 0.004 & $C>E=O$ & 1.309 & $>0.70$ \\
\hline Density of Capitellidae spp. ${ }^{a}$ & $\begin{array}{c}4.0 \pm 1.7 \\
(4.1)\end{array}$ & $\begin{array}{c}2.8 \pm 1.1 \\
(6.8)\end{array}$ & $\begin{array}{c}0.8 \pm 0.4 \\
(1.9)\end{array}$ & $\begin{array}{l}\text { Habitat } \\
\text { Error }\end{array}$ & $\begin{array}{l}0.479 \\
3.061\end{array}$ & $\begin{array}{r}2 \\
21\end{array}$ & 1.645 & 0.217 & & 8.950 & $<0.05$ \\
\hline Density of Sabellidae sp. $1^{\mathrm{a}}$ & $\begin{array}{c}2.3 \pm 1.0 \\
(2.3)\end{array}$ & $\begin{array}{c}0.6 \pm 0.5 \\
(1.5)\end{array}$ & $\begin{array}{c}0.6 \pm 0.3 \\
(1.6)\end{array}$ & $\begin{array}{l}\text { Habitat } \\
\text { Error }\end{array}$ & $\begin{array}{l}0.277 \\
1.785\end{array}$ & $\begin{array}{r}2 \\
21\end{array}$ & 1.628 & 0.220 & & 0.935 & $>0.80$ \\
\hline Density of Spionidae sp. 1 & $\begin{array}{c}0.9 \pm 0.5 \\
(0.9)\end{array}$ & $\begin{array}{c}0.4 \pm 0.2 \\
(0.9)\end{array}$ & $\begin{array}{c}1.0 \pm 0.4 \\
(2.6)\end{array}$ & $\begin{array}{l}\text { Habitat } \\
\text { Error }\end{array}$ & $\begin{array}{r}1.75 \\
22.75 \\
\end{array}$ & $\begin{array}{r}2 \\
21 \\
\end{array}$ & 0.808 & 0.459 & & 5.221 & $>0.10$ \\
\hline
\end{tabular}

${ }^{a}$ Data were log-transformed for ANOVA to secure homogeneity variances. 
Spionidae sp.1 did not differ significantly among positions, whereas those of Capitellidae spp. at both sites and Sabellidae sp. at the HS site did (Table 3). For Capitellidae spp., the relative abundance was highest outside of the $H$. ovalis vegetation at the HS site and lowest at the same position at the HT site (Table 3). For Sabellidae sp., relative abundance varied significantly at the HS site due to its absence outside the vegetation, whereas it did not differ significantly among the three positions at the HT site (Table 3).

\section{DISCUSSION}

The present study shows that the abundance and diversity of benthic animals in the seagrass bed at Laem Yong Lam varied greatly among positions in and near the $H$. ovalis vegetation. The density of Pillucina sp. was greater at the center than at the edge of the vegetation, but did not differ between the edge and outside of the $H$. ovalis vegetation (Table 3). Taxa richness showed a similar pattern of within-site variation, although most of the dominant taxa were found at various positions at each site (Table 3 ). The three positions at each site were close to each other (ca 3-5 m apart), but differed greatly both in seagrass species composition and in aboveground and belowground biomass, reflecting complex spatial configuration of the seagrass habitat (Fig. 1B). The present study demonstrated that such small-scale variation in habitat heterogeneity is important in determining abundance and diversity of benthic communities in the seagrass bed. In contrast to Pillucina sp. and Sabellidae sp., which showed significant among-position variation in density, no significant variation was detected for Spionidae sp.1 and Capitellidae spp. (Table 3). In addition, patterns of among-position variation in relative abundance also varied from taxa to taxa (Table 3 ). These results suggest that the responses of benthic animals to seagrass spatial heterogeneity are species specific.

I expected the patterns of variation in the benthic community in $H$. ovalis vegetation to differ between the HS and HT sites because benthic animals at the vegetation edge are likely to be affected by the different types of surrounding environments. The surrounding environments at the two sites differed not only in the presence or absence of seagrass vegetation ( $T$. hemprichii), but also in tidal level and sediment composition (Table 2). Compared to the unvegetated sand flat near the HS site, the T. hemprichii vegetation had coarser sediment and a shorter exposure time during low tide. These factors may affect abundance of some benthic taxa. However, there were no differences in the patterns of among-position variation at the $\mathrm{HS}$ and $\mathrm{HT}$ sites (Fig. 3 and Table 3 ). Lower taxa richness and densities of some dominant animals in the $T$. hemprichii vegetation than at the center of $H$. ovalis vegetation indicate that $H$. ovalis provides better habitats for most benthic animals than $T$. hemprichii. Compared to $T$. hemprichii, $H$. ovalis covers a larger portion of the sediment surface by producing small but numerous leaves and petioles in the aboveground parts, and more complex networks of rhizomes at shallow parts of the sediment than T. hemprichii (Vermaat et al. 1995; Duarte et al. 1998). Such morphological characters of $H$. ovalis may favor the small-sized benthic animals collected here by providing habitats and refuges, although the mechanisms causing the variation in the benthic animals among different seagrass vegetation remain to be investigated.

Various factors can be considered to be responsible for producing the observed patterns of variation in the benthic community within vegetation, including predation intensity, food availability, physical disturbance, stress, larval supply and subsequent recruitment rate. Concerning predation intensity, major predators of the benthic animals collected at the study site (suspension feeders and deposit feeders mostly smaller than $1 \mathrm{~cm}$ in size) are large and mobile decapod crustaceans and carnivorous fish (Nojima, Junekitkarn \& Duangdee, unpublished data), which were not efficiently collected by the core samples of $0.01 \mathrm{~m}^{2}$ area. At the HS site, the predation rate on infaunal prey species by these large mobile predators may be higher at the edge of the vegetation than at the center because the biomass of $H$. ovalis is lower and predators have easier access to the edge. This may lead to lower densities of some benthic animals at the edge than the center of the vegetation. However, this cannot explain the similar patterns of variation at the HT site where seagrass biomass was highest outside the $H$. ovalis vegetation. Pillucina sp. and Sabellidae sp. are suspension feeders, while the other dominant polychaetes (spionid and capitellid species) are mostly deposit-feeders (Fauchald \& Jumars 1979). It is possible that the presence of $H$. ovalis vegetation alters food conditions in favor of suspension-feeders. Previous studies, however, have shown that the presence of seagrass vegetation can both positively and negatively affect the food availability for suspension feeders (Irlandi \& Peterson 1991; Reusch 1998; Reusch \& Williams 1999). Examination of these possible factors, such as microhabitat variation in 
predation intensity and food conditions, are necessary to elucidate how spatial heterogeneity of seagrass vegetation causes variation in benthic communities.

The growth rate of $H$. ovalis at the edge of the vegetation is rapid (rhizome growth rate: $15 \mathrm{~mm} / \mathrm{d}$ ) when the vegetation borders an unvegetated sand flat (Nakaoka \& Aioi 1999; Nakaoka \& Iizumi 2000). Therefore, the edge of the vegetation at the HS site was probably covered with $H$. ovalis quite recently (within 20 days, assuming a constant growth rate of the rhizomes). A similar level of abundance of benthic animals between the edge and outside of the vegetation is expected when the colonization rate to the newlyextended seagrass vegetation is lower than the expansion rate of the seagrass.

In conclusion, I showed that the benthic community in the seagrass bed at Laem Yong Lam is affected by small-scale spatial heterogeneity of $H$. ovalis vegetation, and that the pattern of variation among positions within the vegetation varied among benthic animals. These findings address the importance of the spatial structure of habitat heterogeneity in quantitative estimation of benthic communities. For example, choosing the center of habitats as sampling stations may lead to an overestimation of the density of some benthic animals when one extrapolates the data of benthic abundance to larger-scales, such as when estimating the biomass in an entire seagrass bed. Appropriate sampling designs taking the effects of small-scale habitat heterogeneity into consideration are thus necessary for precise estimation of abundance and diversity of benthic communities over large scales.

Acknowledgments. I wish to thank K. Lewmanomont, C. Supanwanid, and the staff in Marine National Park Supporting Center, Thailand, for invaluable support in various aspects of this research project. I am grateful to N. Pankao and R. Sooknan for assistance in field works, to T. Arai, Y. Hashiguchi, Y. Okuzaki and F. Suzuki for assistance in laboratory measurements, and to T. Kato, M. Matsumasa, H. Mukai, E. Tsuchida, K. Yabe and R. Yamamoto for taxonomic identification of invertebrate animals. This research was conducted as a part of international scientific research program entitled "Effects of grazing and disturbance by dugongs and turtles on tropical seagrass ecosystems" supported by a grant-in-aid from the Ministry of Education, Science, Culture and Sports, Japan (No. 09041147).

\section{REFERENCES}

Bell, S. S., M. O. Hall and B. D. Robbins 1995. Toward a landscape approach in seagrass beds: using macroalgal accumulation to address questions of scale. Oecologia, 104: 163-168.

Bell, S. S. and G. R. F. Hicks 1991. Marine landscapes and faunal recruitment: a field test with seagrasses and copepods. Marine Ecology Progress Series, 73: 61-68.

Bell, S. S., E. D. McCoy and H. R. Mushinsky 1991. Habitat Structure: the Physical Arrangement of Objects in Space. Chapman and Hall, London, $438 \mathrm{pp}$.

Bologna, P. A. X. and R. S. Steneck 1993. Kelp beds as habitat for American lobster Homarus americanus. Marine Ecology Progress Series, 100: 127-134.

Buchanan, J.B. 1984. Sediment analysis. In, Methods for the Study of Marine Benthos, Holme, N. A. and A. D. McIntyre (eds.), Blackwell Science, Oxford, pp. 41 - 65.

Duarte, C. M., M. Merino, N. S. R. Agawin, J. Uri, M. D. Fortes, M. E. Gallegos, N. Marbà and M. A. Hemminga 1998. Root production and belowground seagrass biomass. Marine Ecology Progress Series, 171: $97-108$.

Eggleston, D. B., L. L. Etherington and W. E. Elis 1998. Organism response to habitat patchiness: species and habitat-dependent recruitment of decapod crustaceans. Journal of Experimental Marine Biology and Ecology, 223: 111-132.

Fauchald, K. and P. A. Jumars 1979. The diet of the worms: a study of polychaete feeding guilds. Oceanography and Marine Biology: an Annual Review, 17: 193284.

Irlandi, E. A. 1994. Large- and small-scale effects of habitat structure on rates of predation: how percent coverage of seagrass affects rates of predation and siphon nipping on an infaunal bivalve. Oecologia, 98: 176-183.

Irlandi, E. A. 1996. The effect of seagrass patch size and energy regime on growth of an infaunal bivalve. Journal of Marine Research, 54: 1-26.

Irlandi, E. A. 1997. Seagrass patch size and survivorship of an infaunal bivalve. Oikos, 78: 511-518.

Irlandi, E. A. and C. H. Peterson 1991. Modification of animal habitat by large plants: mechanisms by which seagrasses influence clam growth. Oecologia, 87: 307318.

Jernakoff, P., A. Brearley and J. Nielsen 1996. Factors affecting grazer-epiphyte interactions in temperate seagrass meadows. Oceanography and Marine Biology: an Annual Review, 34: 109-162.

Lewmanomont, K., S. Deetae and V. Shimanobhas 1996. 
Seagrasses of Thailand. In, Seagrass Biology: Proceedings of an International Workshop, Rottenest Island, Western Australia, 25-29 January 1996, Kuo, J., R. C. Phillips, D. I. Walker and H. Kirkman (eds.), Faculty of Science, The University of Western Australia, Nedlands, Australia, pp. 21-26.

Lewmanomont, K. and C. Supanwanid 2000. Species composition of seagrasses at Haad Chao Mai National Park, Trang Province, Thailand. Kasetsart University Fishery Research Bulletin, 22: 1-9.

Marbà, N. and C. M. Duarte 1995. Coupling of seagrass (Cymodocea nodosa) patch dynamics to subaqueous dune migration. Journal of Ecology, 83: 381-389.

Mazzella, L., M. C. Buia, M. C. Gambi, M. Lorenti, G. F. Russo, M. B. Scipione and V. Zupo 1992. Plant-animal trophic relationships in the Posidonia oceanica ecosystem of the Mediterranean Sea. In, Plant-animal Interactions in the Marine Benthos: Systematics Association Special Volume 46, Price, J. H., D. M. John and S. J. Hawkins (eds.), Clarendon Press, Oxford, pp. 165-187.

Nakaoka, M. and K. Aioi 1999. Growth of the seagrass Halophila ovalis at the dugong trails compared to existing within-patch variation in a Thailand intertidal flat. Marine Ecology Progress Series, 184: 97-103.

Nakaoka, M. and H. Iizumi 2000. Magnitude of withinpatch variation in seagrass Halophila ovalis growth affected by adjacent Thalassia hemprichii vegetation. Ecological Research, 15: 415-424.

Nakaoka, M. and C. Supanwanid 2000. Quantitative estimation of the distribution and biomass of seagrass at Haad Chao Mai National Park, Trang Province, Thailand. Kasetsart University Fishery Research Bulletin, 22: $10-22$.

Nakaoka, M. and T. Toyohara 2000. Effects of seagrass patch structure on the mobile epifaunal community in a subtidal seagrass meadow in Thailand. Benthos Research, 55: 53-61.

Noda, T. 1999. Within- and between-patch variability of predation intensity on the mussel Mytilus trossulus Gould on a rocky intertidal shore in Oregon, USA. Ecological Research, 14: 193-203.

Orth, R. J. 1992. A perspective on plant-animal interactions in seagrasses: physical and biological determinants influencing plant and animal abundance. In, Plant-animal Interactions in the Marine Benthos: Systematics Association Special Volume 46, Price, J. H., D. M. John and S. J. Hawkins (eds.), Clarendon Press, Oxford, pp. 147-164.

Orth, R. J. and J. van Montfrans 1984. Epiphyte-seagrass relationships with an emphasis on the role of micrograzing: a review. Aquatic Botany, 18: 43-69.

Paine, R. and S. Levin 1981. Intertidal landscapes; disturbance and the dynamics of pattern. Ecological Monographs, 51: 145-178.

Reusch, T. B. H. 1998. Differing effects of eelgrass Zostera marina on recruitment and growth of associated blue mussels Mytilus edulis. Marine Ecology Progress Series, 167: 149-153.

Reusch, T. B. H. and S. L. Williams 1999. Macrophyte canopy structure and the success of an invasive marine bivalve. Oikos, 84: 398-416.

Robbins, B. D. and S. S. Bell 1994. Seagrass landscapes: a terrestrial approach to the marine subtidal environment. Trends in Ecology and Evolution, 9: 301-304.

Robinson, S., F. Thompson III, T. Donovan, D. Whitehead and J. Faaborg 1995. Regional forest fragmentation and the nesting success of migratory birds. Science, 267: 1987-1990.

Saunders, D., R. Hobbs and C. Margules 1991. Biological consequences of ecosystem fragmentation: a review. Conservation Biology, 5: 18-32.

Sousa, W. 1984. Intertidal mosaics: patch size, propagule availability, and spatially variable patterns of succession. Ecology, 65: 1918-1935.

Stoner, A. W. and F. G. Lewis 1985. The influence of quantitative and qualitative aspects of habitat complexity in tropical seagrass meadows. Journal of Experimental Marine Biology and Ecology, 94: 19-40.

Tilman, D. 1994. Competition and biodiversity in spatially structured habitats. Ecology, 75: 2-16.

Tilman, D. and P. Kareiva 1997. Spatial Ecology: the Role of Space in Population Dynamics and Interspecific Interactions. Princeton University Press, Princeton, 368 pp.

Underwood, A. J. 1997. Experiment in Ecology: Their Logical Design and Interpretation Using Analysis of Variance. Cambridge University Press, Cambridge, 504 pp.

Vermaat, J. E., N. S. R. Agawin, C. M. Duarte, M. D. Fortes, N. Marbà and J. S. Uri 1995. Meadow maintenance, growth and productivity of a mixed Philippine seagrass bed. Marine Ecology Progress Series, 124: 215225.

Vidondo, B., C. M. Duarte, A. L. Middelboe, K. Stefansen, T. Luetzen and S. L. Nielsen 1997. Dynamics of a landscape mosaic: size and age distributions, growth and demography of seagrass Cymodocea nodosa patches. Marine Ecology Progress Series, 158: 131-138. 